\title{
Anti-Oxidant and Hepatoprotective Effects of Senecio biafrae on CCl4-induced Liver Damage in Rats
}

\section{Israel Oghenevwodoko Okoro*iD, Helen Ejiro Kadiri}

Department of Biochemistry, Delta State University, Abraka, Delta State, Nigeria.

\begin{tabular}{ll}
\hline Article Info & A B S T R A C T \\
\hline Article type: & Background: \\
Original Article & The present study was performed to explore whether the aqueous extract \\
\hline Article History: & of Senecio biafrae $($ S. biafrae) roots provide any in vivo protective activity \\
Received: $2019-02-23$ & against carbon tetrachloride (CCl4)-induced hepatotoxicity in male albino \\
Accepted: $2019-04.17$ & rats.
\end{tabular}

Methods:

\section{* Corresponding author:}

Israel Oghenevwodoko Okoro

Department of Biochemistry, Delta

State University, Abraka, Delta State,

Nigeria.

E-mail: israelik@yahoo.com
Rats (150-200 grams) were grouped into five groups (A-E) of six rats each and were treated orally for twelve days with 72 hourly administration of CCl4 $(1 \mathrm{~mL} / \mathrm{kg})$ as follows: Group A received distilled water only (negative control), Group $B$ was administered distilled water plus CCl4 (positive control), Group $C$ was administered $400 \mathrm{mg} / \mathrm{kg}$ extract and CCl4, Group $D$ received $200 \mathrm{mg} /$ extract and $\mathrm{CCl} 4$, while Group $E$ was administered standard drug (Silymarin $25 \mathrm{mg} / \mathrm{kg}$, PO).

Results:

Pre-treatment with the extract of $S$. biafrae $(200$ or $400 \mathrm{mg} / \mathrm{kg}$ ) or Silymarin $(25 \mathrm{mg} / \mathrm{kg})$ caused significant restoration in the biomarkers as evaluated by reducing the levels of malondialdehyde, transaminases and elevating the levels of superoxide dismutase, catalase and glutathione peroxidase activities, which were altered by $\mathrm{CCl} 4$ toxicity. The extract at a dose of $400 \mathrm{mg} / \mathrm{kg}$ demonstrated similar activities comparable to the standard drug (Silymarin).

\section{Conclusion:}

The results of this study indicate that the root extract of $S$. biafrae possesses hepatoprotective and anti-oxidant properties which may be due to the presence of phytochemicals in it.

Keywords:

Anti-Oxidant; Carbon Tetrachloride; Hepatoprotective; Senecio Biafrae; Silymarin.

How to cite this paper

Okoro IO, Kadiri HK. Anti-Oxidant and Hepatoprotective Effects of Senecio biafrae on CCl4-induced Liver Damage in Rats. Iran J Toxicol. 2019; (2): 31-35

\section{INTRODUCTION}

Carbon tetrachloride $\left(\mathrm{CCl}_{4}\right)$-induced liver damage is an oxidative-stress model employed for screening of hepatoprotective compounds ( $\underline{1})$. Carbon tetrachloride is known to induce hepatotoxicity by exerting oxidative stress on the organ. A relationship between lipid peroxidation and oxidative stress has previously been described (2). Trichloromethyl radical $\left(\mathrm{CCl}_{3} \bullet\right)$, a metabolite (toxic intermediate) from the cytochrome $\mathrm{P}_{450}$ system of enzymes in liver microsomes, is reported to give rise to liver damage. $\mathrm{CCl}_{4}$-induced liver damage progresses from steatosis to centrilobular necrosis, thereby developing fibrosis and cirrhosis ( $\underline{3})$.

The liver has an important role in nutrients metabolism and chemicals. It is also involved in the excretion of xenobiotics from the body and providing protection against harmful foreign materials through detoxification and elimination (므). Liver injury arising from several etiologies are said to cause steady failure in hepatic functions. Free radicals, food additives, alcohol, pollutants and xenobiotics are the key risk factors leading to cirrhosis, alcoholic liver diseases and hepatitis ( $\underline{5})$.

Treatment of liver-related diseases is important and should be handled with utmost care. Not all conventional drugs available for regeneration of liver cells are without hepatotoxic side effects ( Therefore, it is essential to explore safe and hepatoprotective agents, in the context of traditional and medical knowledge (7). S. biafrae is a naturally occurring herb found in African forest areas. It is used as a green leafy vegetable in Sierra Leone, Benin, 
Nigeria, Ghana, Cameroon and Gabon. It contains several metabolites like sesquiterpenes, dihydroisocoumarins, amino acids and terpenoids (므). It is used in Nigeria for the treatment of pulmonary conditions and women infertility ()ㅡ. The plant has been reported to have antimicrobial ( $\underline{10})$ and antihypertensive properties (11). Similarly, its antidiabetic and physicochemical properties have previously been reported (12). Our findings from traditional healers about the herb in the Niger Delta revealed that the root has been used for the treatment of liver-related diseases amongst others. Considering that other species of Senecio have shown hepatoprotective activity $(\underline{13})$ and the phytochemical profile of the plant $(10,14)$, the present study was performed to investigate whether the aqueous extract of $S$. biafrae roots demonstrate any in vivo protective activity against $\mathrm{CCl} 4$-induced liver damage in rats.

\section{MATERIALS AND METHODS}

Reagents and Chemicals: Silymarin and $\mathrm{CCl} 4$ were purchased from Sigma chemicals (St. Louis, USA). Diagnostic kits for serum total bilirubin (TBIL), Albumin (ALB), Total protein (TP), aspartate aminotransferase (AST), alkaline phosphatase (ALP) and alanine aminotransferase (ALT) were purchased from Randox Laboratories Ltd. (Ardmore, UK). All other chemicals for this experiment were obtained locally, and were of analytical grade.

Plant Material: The roots of S. biafrae were collected from Akoko, Ondo State, Nigeria, and authenticated by Dr. H.A. Akinnobosun of the Department of Plant Science (Reference voucher \#: UBHs 0149), University of Benin, Edo State, Nigeria.

Preparation of Plant Materials: The collected, shade dried roots were pulverized to fine powder by pestle and mortar. They were extracted with distilled water by soaking fifty grams in $200 \mathrm{~mL}$ of the solvent in airtight flask and shaken daily for three days. The mixture was filtered through muslin cloth and Whatman No. 1 filter paper and concentrated under reduced pressure and low temperature using a rotary evaporator. The resultant extract was kept at $4^{\circ} \mathrm{C}$ before use. Afterwards, the dried extract were suspended in distilled water to prepare the two concentrations $(400 \& 200 \mathrm{mg} / \mathrm{ml})$ for the purpose of this study.

Animals: The male albino rats (weighing 150-200g) were bought from the Anatomy Department of Delta State University, Abraka, Nigeria. They were fed grower's mash (Top Feeds, Ltd, from Sapele in Delta State, Nigeria) and water ad libitum. The animals were maintained in agreement with the guidelines of the institutional Committee for the Care and Use of Laboratory Animals (Publication No. 85-23, revised 1985).

Grouping and Treatment of Animals: The rats were divided into five groups (A-E) of six rats each and were treated orally for twelve days as follows: Group A received distilled water only (negative control), Group $B$ was administered distilled water plus $\mathrm{CCl} 4$ (positive control), Group $C$ was administered $400 \mathrm{mg} / \mathrm{kg}$ extract and CCl4, Group D received $200 \mathrm{mg}$ /extract and $\mathrm{CCl} 4$, while Group $E$ was administered the standard drug (Silymarin $25 \mathrm{mg} / \mathrm{kg}, \mathrm{PO}$ ). The $\mathrm{CCl} 4$ was given at a dose of $1 \mathrm{~mL} / \mathrm{kg}$ of body weight (BW; $30 \%$ concentration in liquid paraffin) 72 hours after the first extract or Silymarin administration and subsequently every other 72 hours. The animals were sacrificed by decapitation 24 hours after the last administration to obtain their blood and organs, which were used for the biochemical assays. The blood was allowed to clot after collection and centrifuged at $3000 \times \mathrm{g}(15 \mathrm{~min})$, while the liver tissues were homogenized in phosphate buffer $(\mathrm{pH} 7.4)$ and centrifuged at $3000 \mathrm{~g}$ for $10 \mathrm{~min}$. Thereafter, the supernatants were collected and used for the assays.

\section{Determination of Serum Hepatospecific}

Markers: The activities of serum aspartate aminotransferase (AST), alkaline phosphatase (ALP), alanine aminotransferase (ALT), total bilirubin (TBIL), albumin (ALB) and total protein (TP) were tested by assay kits, obtained from Randox Laboratories Ltd. (Ardmore, UK).

Determinations of Antioxidant Activity In Vivo: The levels of lipid peroxidation was evaluated based on the reaction of two moles of $\mathrm{N}$-methyl-2-phenylindole, a chromogenic reagent, with one mole of either malondialdehyde (MDA) or

4-HNE at $45^{\circ} \mathrm{C}$ for $60 \mathrm{~min}$ to yield a stable chromophore with a maximum absorbance at $586 \mathrm{~nm}$ as described elsewhere (15). Catalase activity was evaluated according to the method of Aebi ( $\underline{16})$. Glutathione peroxidase activity was determined following NADPH oxidation at $340 \mathrm{~nm}$ in the presence of excess reduced glutathione, glutathione reductase and corresponding peroxide ( $\underline{17})$. Liver superoxide dismutase (SOD) activity was evaluated according to the method described by Kakkar et al. (18), while glutathione-S-transferase (GST) activity was estimated by the method of Habig et al. (19).

Statistical Analysis: The results were calculated by the Graph pad Prism 6 software using one-way ANOVA followed by Tukey-Kramer multiple comparisons test. A confidence level of $\mathrm{p}<0.05$ was considered significant. The values shown in Tables 1 and 2 are as means \pm standard deviation (SD).

\section{RESULTS}

Biochemical Changes in Serum Markers: The effects of aqueous extracts of $S$. biafrae on the liver function of $\mathrm{CCl}_{4}$ intoxicated rats, after twelve days of treatment, are shown in Table 1 . The administration of $\mathrm{CCl}_{4}$ significantly $(\mathrm{p}<0.05)$ increased ALT and AST levels in the positive control group $B$, compared to those in negative control group A. Also, a significant increase $(\mathrm{p}<0.05)$ in ALP and TBIL levels were found in group $B$ rats relative to those in normal control group A. On the other hand, treatment with either the extract or the standard drug significantly $(p<0.05)$ reduced the levels of serum hepatic enzymes ALT, AST \& ALP and TBIL, compared with those in positive control group B. However, lower levels of albumin and total protein 
were noticed in group B rats, compared with those in negative control group A. Significantly $(p<0.05)$ higher levels of these two parameters were detected in the rats that received either a higher dose of extract (group C) or the standard drug (group E).

\section{Effect of Aqueous Root Extracts of S. Biafrae on} Liver Biochemical Parameters: Liver biochemical parameters such as SOD, CAT, GST and glutathione peroxidase (GPX) were reduced while lipid peroxidation increased in $\mathrm{CCl}_{4}$-induced rats (Group B) compared to the negative controls (Group A) as shown in Table 2. Treatment with either the extract or the standard drug restored the level of these oxidative stress markers to near normal. Thus, a striking increase in the MDA level was seen in the liver of Group B $\left(\mathrm{CCl}_{4}\right.$ exposed) rats relative to normal controls in Group $A$ rats (Table 2). The increase in MDA was statistically significant $(\mathrm{p}<0.05)$. Likewise, the group treated with $400 \mathrm{mg} / \mathrm{kg}$ of $S$. biafrae extract had lower MDA levels compared to those in the standard group. Thus, the highest dose $(400 \mathrm{mg} / \mathrm{kg})$ of $S$. biafrae extract and Silymarin showed the best results.

Table 1. Effect of $S$. biafrae aqueous extract on the biochemical parameters in carbon tetrachloride-induced hepatotoxicity.

\begin{tabular}{llllll}
\hline \multicolumn{1}{c}{ Parameters } & \multicolumn{1}{c}{ Group A } & \multicolumn{1}{c}{ Group B } & \multicolumn{1}{c}{ Group C } & Group D & Group E \\
\hline ALT (U/L) & $36.32 \pm 0.86^{\mathrm{b}}$ & $93.32 \pm 2.86^{\mathrm{a}}$ & $40.25 \pm 1.76^{\mathrm{a}} \mathrm{b}$ & $56.05 \pm 2.13^{\mathrm{a}} \mathrm{b}$ & $32.4 \pm 1.25^{\mathrm{a}} \mathrm{b}$ \\
AST (U/L) & $48.24 \pm 0.89^{\mathrm{b}}$ & $162.42 \pm 5.74^{\mathrm{a}}$ & $45.19 \pm 2.88^{\mathrm{b}}$ & $71.19 \pm 1.93^{\mathrm{a}} \mathrm{b}$ & $43.01 \pm 2.56^{\mathrm{a}}$ \\
ALP (U/L) & $72.29 \pm 1.88^{\mathrm{b}}$ & $195.37 \pm 6.02^{\mathrm{a}}$ & $78.53 \pm 3.47^{\mathrm{b}}$ & $94.44 \pm 2.72^{\mathrm{a}} \mathrm{b}$ & $63.25 \pm 3.29 \mathrm{ab}$ \\
TP (mg/dl) & $7.53 \pm 0.81^{\mathrm{b}}$ & $4.09 \pm 0.68^{\mathrm{a}}$ & $6.74 \pm 0.38^{\mathrm{b}}$ & $5.2 \pm 0.64^{\mathrm{a}}$ & $7.31 \pm 0.47^{\mathrm{b}}$ \\
ALB (g/dl) & $2.49 \pm 0.31^{\mathrm{b}}$ & $1.18 \pm 0.09^{\mathrm{a}}$ & $2.64 \pm 0.37^{\mathrm{b}}$ & $1.49 \pm 0.22^{\mathrm{a}}$ & $2.38 \pm 0.25^{\mathrm{b}}$ \\
TBIL (mg/dl) & $1.13 \pm 0.07^{\mathrm{b}}$ & $3.12 \pm 0.17^{\mathrm{a}}$ & $1.45 \pm 0.12^{\mathrm{ab}}$ & $2.15 \pm 0.11^{\mathrm{ab}}$ & $2.00 \pm 0.17^{\mathrm{a}} \mathrm{b}$ \\
\hline
\end{tabular}

Key: ${ }^{\mathrm{a}} \mathrm{p}<0.05$ vs. negative controls; ${ }^{\mathrm{b}} \mathrm{p}<0.05$ vs. positive controls.

Table 2. Effect of Senecio biafrae aqueous extract on SOD, CAT, GPx, GST and MDA in CCl 4 -induced hepatotoxicity.

\begin{tabular}{|c|c|c|c|c|c|}
\hline Parameters & Group A & Group B & Group C & Group D & Group E \\
\hline SOD (U/mg protein) & $73.4 \pm 1.61^{b}$ & $28.24 \pm 0.66^{\mathrm{a}}$ & $61.65 \pm 1.31$ a b & $51.8 \pm 2.27 \mathrm{ab}$ & $66.19 \pm 1.13^{\text {a b }}$ \\
\hline CAT (U/mg Protein) & $132.39 \pm 1.13^{b}$ & $40.43 \pm 2.03^{\mathrm{a}}$ & $109.06 \pm 2.14 \mathrm{ab}$ & $76.34 \pm 2.84$ a b & $120.19 \pm 2.98 \mathrm{ab}$ \\
\hline GPx (U/mg protein) & $14.25 \pm 0.51^{b}$ & $6.72 \pm 0.5^{a}$ & $9.81 \pm 0.6^{\mathrm{ab}}$ & $7.62 \pm 0.37 \mathrm{a}$ & $10.92 \pm 0.43$ a b \\
\hline GST (U/mg protein) & $8.15 \pm 0.49^{b}$ & $3.07 \pm 0.53^{\mathrm{a}}$ & $6.11 \pm 0.59 \mathrm{ab}$ & $4.15 \pm 0.46^{\mathrm{a}}$ & $7.04 \pm 0.22^{\mathrm{ab}}$ \\
\hline MDA (nmol/mg protein) & $6.08 \pm 0.64 \mathrm{~b}$ & $12.79 \pm 0.82^{\mathrm{a}}$ & $6.20 \pm 0.43^{b}$ & $8.48 \pm 0.46^{\mathrm{ab}}$ & $6.73 \pm 0.56^{b}$ \\
\hline
\end{tabular}

\section{DISCUSSION}

The maintenance of body homeostasis is one of the major functions of the liver. Carbon tetrachlorideinduced liver damage is an oxidative stress model employed for screening of hepatoprotective chemicals and drugs (20). Liver transaminases, such as AST and ALT still remain the best standards for the evaluation of liver injury and have been the preferred biomarkers for decades (21). In this study, significant liver necrosis supported by increased levels of total bilirubin, liver marker enzymes activities (ALT, AST and ALP), and decreased levels of albumin and total protein were observed in the rats treated with $\mathrm{CCl}_{4}$ (Group B). But pretreatment with S.biafrae extract $(200$ and $400 \mathrm{mg} / \mathrm{kg}, \mathrm{BW}$ ) for twelve days resulted in a significant decrease of the $\mathrm{CCl}_{4}$-induced elevation of enzyme markers in serum, comparable to the effect of the standard drug, Silymarin. This drug is a well-known hepatoprotective compound derived from Silybum marianum and its protective effect on the plasma membrane of hepatocytes has been shown (22). The significant reduction in the total protein and albumin observed in $\mathrm{CCl}_{4}$-treated rats might be as a result of functional failure in the cytochrome- $\mathrm{P}_{450}$ complexes $(\underline{23})$. Thus, the result indicate that pre-treatment of $S$. biafrae extract, caused restoration to normal, the activities of serum marker enzymes and the levels of total protein, total bilirubin and albumin, thus indicating that $S$. biafrae extract maintained the structural integrity of hepatocellular constituents and kept the liver from $\mathrm{CCl}_{4}$-induced injury in vivo (24).
An essential mechanism in the protection of liver against $\mathrm{CCl}_{4}$-induced damage is the inhibition of excess reactive oxygen species (ROS) production. MDA is commonly used as a major parameter and marker of lipid peroxidation when assessing the status of oxidative stress (25). In this study, we observed an elevated level of liver MDA in the $\mathrm{CCl}_{4}$-treated rats, which implies an increase in lipid peroxidation with the consequent damage to tissue and breakdown of the antioxidant defense mechanisms to stop formation of excess free radicals. This result is in agreement with the previous reports that $\mathrm{CCl}_{4}$ caused hepatic injury by elevating the MDA level (26). However, we also observed that pretreatment with the extract significantly decreased the $\mathrm{CCl}_{4}$-induced liver $\mathrm{MDA}$ elevation. Therefore, the mechanism of hepatoprotection of $S$. biafrae extract may be due its antioxidant potential $(\underline{12,27})$.

Super oxide dismutase functions by removing reactive oxygen radicals and preventing the production of more hydroxyl radicals, thus considered as the initial line of cellular defense against oxidative stress (르). Catalase is a heme-containing enzyme localized largely in the subcellular organelles (peroxisomes) that converts $\mathrm{H}_{2} \mathrm{O}_{2}$ to water and $\mathrm{O}_{2}$, and protects the cell from oxidative damage caused by $\mathrm{H}_{2} \mathrm{O}_{2}$ and $\mathrm{OH}$ group. It has been established that $\mathrm{CCl}_{4}$, in addition to initiating lipid peroxidation, also reduces CAT and SOD activities in the tissue, which may be caused by oxidative alteration of these proteins (29). In this study, a decrease in the activities of SOD and CAT was noted in the $\mathrm{CCl}_{4}$-treated groups, thus suggesting liver injury in the rats. 
However, the rats treated with 200 and $400 \mathrm{mg} / \mathrm{kg} \mathrm{BW}$ of $S$. biafrae showed significant increase in the level of these enzymes, suggestive of the antioxidant effect of the extract (12).

Glutathione peroxidase (GSH-Px) is an essential enzyme which catalyzes the reduction of lipid hydroperoxides and $\mathrm{H}_{2} \mathrm{O}_{2}$ into $\mathrm{H}_{2} \mathrm{O}$ and resultant alcohols and thereafter, terminating the processes of lipid peroxidation ( $\underline{30})$. Glutathione-S-transferase (GST) is an enzyme that catalyzes the conjugation of GSH through the sulfhydryl group. It participates in the detoxification process resulting from conjugation reaction between xenobiotics and GSH (피). The activity of GST is valuable in the endogenous detoxification of compounds, such as peroxidized lipids (32). In this study, a decrease in the activity of this enzyme, in $\mathrm{CCl}_{4}$-treated rats and a reversal close to normalcy in the extract or the standard drug treated rats were shown. Thus, pretreatment with $S$. biafrae led to a rise in GST activity and a decrease in the liver MDA, thereby suggesting that the protective effect $S$. biafrae may be linked to its anti-oxidative stress function.

The observed effects of $S$. biafrae extract in this study may be attributed partly to several phytoconstituents present in it, such as alkaloids, saponins, tannins, glycosides, phenols, $\quad \beta$ Carotenes, flavonoids, cardenolides, anthraquinones and steroids $(\underline{10,14})$. These phytoconstituents could generally have contributed to the detected hepatoprotective and antioxidant activities of the plant (3-35).

\section{CONCLUSION}

Administration of $\mathrm{CCl}_{4}$ at $1 \mathrm{ml} / \mathrm{kg}$ body weight to Wistar male rats resulted in an increase in lipid peroxidation and reduction in enzymatic antioxidants. S. biafrae extract, at 200 or $400 \mathrm{mg}$ dosage showed hepatoprotective effects, but $400 \mathrm{mg} / \mathrm{kg}$ was more effective, compared with the effect of standard drug, Silymarin. We conclude that $S$. biafrae extract had antioxidant and protective activities against $\mathrm{CCl}_{4}$ hepatotoxicity in Wistar albino male rats, which is likely due to its ability to scavenge free radicals and reduce inflammatory responses. However, further studies are highly recommended to identify the active components of the extract and the molecular mechanisms responsible for the hepatoprotective effect.

\section{ACKNOWLEDGEMENTS}

The technical support of Mrs. Edith Omozefe Okoro of Emmanuel medical laboratory in Abraka is highly appreciated.

\section{CONFLICT OF INTEREST}

The authors declared that there was no conflict of interest in conducting this study.

\section{REFERENCES}

1. Weber LWD, Boll M, Stampfl A. Hepatotoxicity and mechanism of action of haloalkanes: carbon tetrachloride as a toxicological model. Crit. Rev. Toxicol. 2003;33:10536.

2. Basu S. Carbon tetrachloride-induced hepatotoxicity: a classic model of lipid peroxidation and oxidative stress. In: Basu S, Wiklund L, editors. Studies on experimental models. Humana Press, New York. 2011, p 467-80.

3. Lu B, Xu Y, Xu L, Cong X, Yin L, Li H, et al. Mechanism investigation of dioscin against $\mathrm{CCl} 4$-induced acute liver damage in mice. Environ. Toxicol. Pharmacol. 2012;34(2):127-35.

4. Desai SN, Patel DK, Devkar RV, Patel PV, Ramachandran AV. Hepatoprotective potential of polyphenol rich extract of Murraya koenigii L.: an in vivo study. Food Chem. Toxicol. 2012;50:310-4.

5. Valko M, Leibfritz D, Moncol J, Cronin M, Mazur M, Telser J. Free radicals and antioxidants in normal physiological functions and humandisease, Int. J Biochem Cell Biol. 2007;39:44-84.

6. Gagliano N, Grizzi F, Annoni G. Mechanism of aging and liverfunctions, Dig. Dis. Sci. 2007;25:118-23.

7. Jain M, Kapadia R, Jadeja RN, Thounaojam MC, Devkar $\mathrm{RV}$, Mishra SH. Protective role of standardized Feronia limonia stem bark methanolic extract against carbon tetrachloride induced hepatotoxicity. Ann. Hepatol. 2012;11(6):935-43.

8. Tabopda TK, Fotso GW, Ngoupayo J, Mitaine-Offer AC, Ngadjui BT, Lacaille- Dubois MA. Antimicrobial dihydroisocoumarins from Crassocephalum biafrae. Plant Med. 2009;75:1258-61.

9. Lienou LL, Telefo PB, Bayala B, Yemele MD, Lemfack MC, Mouokeu C, et al. Effect of ethanolic extract of Senecio biafrae on puberty onset and fertility in immature female rats. Cam. J Experiment Biol. 2010; 6:101-9.

10. Gbadamosi IT, Okolosi O. Botanical galactogogues: Nutritional and therapeutic potentials. J Appl. Biosci. 2013;61: 4460- 9 .

11. Gbolade A. Ethnobotanical study of plants used in treating hypertension in Edo State of Nigeria. J Ethnopharmacol. 2012;144: 1-10.

12. Okoro IO, Umar I A, Atawodi SE, Anigo KM. Comparative antihyperglycemic effect of petroleum ether, acetone, ethanol and aqueous extracts of Cleome rutidosperma DC and Senecio biafrae (Oliv. \& Hiern) in streptozotocininduced diabetic mice. Br. J Pharmacol. Toxicol. 2014;5(3):115-24.

13. Sohn, S, Lee H, Lee B, Kim S, Shin M, Hong M, et al. Screening of Herbal Medicines for Recovery of Acetaminophen-induced Hepatotoxicity, Mol. Cell. Toxicol. 2008;4(4):331-7.

14. Okoro IO, Umar I A, Atawodi SE, Anigo KM. Antidiabetic effect of Cleome rutidosperma DC and Senecio biafrae (Oliv. \& Hiern) extracts in streptozotocin-induced diabetic rats. Int. J Pharm. Sci. Res. 2014;5(6): 2480-97.

15. Kamalakannan K, Balakrishnan V. Anti-oxidant and hepatoprotective activity of ethanolic and aqueous extracts of Limonia elephantum leaves. Bangladesh J Pharmacol. 2014;9:383-8.

16. Aebi H. Catalase. In: Methods in enzymatic analysis. Bergmeyar HU (eds). New York, Academic Press, 1974, pp 674-84. 
17. Lawrence RA, Burk RF. Glutathione peroxidase activity in selenium deficient rat liver. Biochem Biophys Res Commun. 1976;71:952-8.

18. Kakkar P, Das B, Viswanathan PN. A modified spectrophotometric assay of superoxide dismutase. Indian J Biochem Biol. 1984;21:130-2.

19. Habig WH, Pabst MJ, Jakoby WB. Glutathione Stransferase. The first enzymatic step in mercapturic acid formation. J Biol. Chem.1974; 249:7130-9.

20. Mao X, Lv M, Yu B, He J, Zheng P, Yu J, et al. The effect of dietary tryptophan levels on oxidative stress of liver induced by diquat in weaned piglets. J Anim. Sci. Biotechnol. 2014; 5(1):49. Doi: 10.1186/2049-1891-549.

21. Howell BA, Siler SQ, Shoda LK, Yang Y, Woodhead JL, Watkins PB. A mechanistic model of drug-induced liver injury AIDS, the interpretation of elevated liver transaminase levels in a phase I clinical trial. CPT Pharmacometrics Syst Pharmacol. 2014 Feb 5;3:e98. Doi: 10.1038/psp.2013.74

22. Ramellini G, Meldoles J. Liver protection by silymarin: In vitro effect on dissociated rat hepatocytes. ArzneimittelForschung. Drug Res. 1976;26(1):69-73.

23. Amresh G, Kant R, Zeashan H, Gupta RJ, RaoChVm, Singh PN. Gastroprotective effects of ethanolic extracts from Cissampelo spareira in experimental animals. J Nat Med. 2007; 6:323-8.

24. Ghaffari HM, Venkataramana S, Chandra Nayaka BJ, Ghassam N, Angaswamy S, Shekar KK, et al. Hepatoprotective action of Orthosiphon diffuses (Benth.) methanol active fraction through antioxidant mechanisms: An in vivo and in vitro evaluation. $J$ Ethnopharmacol. 2013;149(3):737-44.

25. You Y, Yoo S, Yoon HG, Park J, Lee YH, Kim S, et al. In vitro and in vivo hepatoprotective effects of the aqueous extract from Taraxacum officinale (dandelion) root against alcohol-induced oxidative stress. Food Chem. Toxicol. 2010;48:1632-7.

26. Al-Sayed E, El-Lakkany NM, Seif El-Din SH, Sabra AN, Hammam OA. Hepatoprotective and antioxidant activity of Melaleuca styphelioides on carbon tetrachlorideinduced hepatotoxicity in mice. Pharm Biol. 2014;52(12):1581-90.
27. Adefegha SA, Oboh G. Cooking enhances the antioxidant properties of some tropical green leafy vegetables. Afr J Biotechnol. 2011;10(4): 632-9.

28. Zhang G, Zhu J, Zhou Y, Wei Y, Xi L, Qin H, et al. Hesperidin Alleviates Oxidative Stress and Upregulates the Multidrug Resistance Protein 2 in Isoniazid and Rifampicin-Induced Liver Injury in Rats. J Biochem Mol Toxicol. 2016;30: 342-9.

29. Augustyniak A, Wazkilwicz E, Skrzydlewaka E. Preventive action of green tea from changes in the liver antioxidant abilities of different aged rats intoxicated with ethanol. Nutrition. 2005;21:925-32.

30. Zhao P, Qi C, Wang G, Dai X, Hou X. Enrichment and purification of total flavonoids from Cortex Juglandis Mandshuricae extracts and their suppressive effect on carbon tetrachloride-induced hepatic injury in Mice. J Chromatogr B Analyt Technol Biomed Life Sci. 2015, Dec. 15;1007:8-17. Doi: 10.1016/j.jchromb.2015.10.019. Epub 2015 Nov 9.

31. Adang AE, Brussee J, Van Der Gen A, Mulder G J. The glutathione-binding site in glutathione Stransferases. Investigation of the cysteinyl, glycyl and gammaglutamyl domains. Biochem J. 1990;269: 47-54.

32. Valavanidis A, Vlahogiannia T, Dassenakis M, Scoullos M. Molecular biomarkers of oxidative stress in aquatic organisms in relation to toxic environmental pollutants. Ecotoxicol Environ Safety. 2006; 64:178-89.

33. El-Sawi SA, Sleem AA. Flavonoids and hepatoprotective activity of leaves of Senna Surattensis (Burm.f) In CCl4 induced hepatotoxicity in rats. Aust J Basic Appl Sci. 2010; 4:1326-34.

34. Shimoda H, Tanaka J, Kikuchi M, Fukuda T, Ito H, Hatano $\mathrm{T}$, et al. Walnut polyphenols prevent liver damage induced by carbon tetrachloride and D-galactosamine: Hepatoprotective hydrolysable tannins in the kernel pellicles of walnut. J Agric Food Chem. 2008; 56:4444-9.

35. Malešev D, Kunti V. Investigation of metal-flavonoid chelates and the determination of flavonoids via metalflavonoid complexing reactions. J Serb Chem Soc. 2007;72(10):921-39. 